\title{
KONSENTRASI PUPUK ORGANIK CAIR (POC) NASA DAN TEKNIK APLIKASI TERHADAP HASIL TANAMAN MENTIMUN (Cucumis sativus L.)
}

\author{
Putri Cahya Anggraeny $^{1)}$, Murti Astiningrum ${ }^{1)}$, Adhi Surya Perdana ${ }^{1)}$ \\ ${ }^{1}$ Program Studi Agroteknologi, Fakultas Pertanian, Universitas Tidar \\ Email : putri.cahyaanggraeny69@gmail.com; murti_astiningrum@yahoo.com; \\ adhisuryaperdana@untidar.ac.id
}

$\begin{array}{ll}\text { Diterima } & : 15 \text { Maret } 2020 \\ \text { Disetujui } & : \text { 25 Agustus } 2020 \\ \text { Diterbitkan } & : 31 \text { Agustus 2020 }\end{array}$

\begin{abstract}
ABSTRAK
Budidaya tanaman mentimun (Cucumis sativus L.) di wilayah Kecamatan Bandongan, Kabupaten Magelang masih terbatas dan belum dibudidayakan secara intensif karena petani belum menggunakan pupuk organik. Pupuk organik dapat diberikan dalam bentuk cair dan perlu diperhatikan konsentrasi serta cara aplikasi yang tepat. Penelitian ini bertujuan untuk mengetahui konsentrasi pupuk organik cair dan teknik aplikasi yang memberikan hasil tertinggi pada tanaman mentimun serta menganalisis interaksi antara konsentrasi dan teknik aplikasi pupuk organik cair terhadap hasil tanaman mentimun. Penelitian dilaksanakan pada bulan Juni hingga Agustus 2019 di Desa Banyuwangi, Kecamatan Bandongan, Kabupaten Magelang, dengan ketinggian tempat $382 \mathrm{~m}$ dpl, jenis tanah Latosol dan $\mathrm{pH}$ 6,6. Penelitian dilakukan menggunakan percobaan faktorial (4 x 2) yang disusun dalam rancangan acak kelompok lengkap dengan tiga blok. Faktor pertama konsentrasi pupuk organik cair : 0, 2, 4, dan $6 \mathrm{ml} / \mathrm{L}$. Faktor kedua teknik aplikasi pupuk : disemprot dan dikocor. Data yang diperoleh dianalisis dengan sidik ragam dan dilanjutkan dengan uji orthogonal polynomial dan uji BNT untuk faktor pertama dan uji - t untuk faktor kedua. Hasil analisis menunjukkan bahwa konsentrasi pupuk organik cair $2 \mathrm{ml} / \mathrm{L}$ memberikan hasil tertinggi pada parameter panjang tanaman, berat per buah, panjang buah dan volume buah. Perlakuan teknik aplikasi pupuk organik cair dan interaksi antara konsentrasi dan teknik aplikasi pupuk organik cair memberikan hasil yang berbeda tidak nyata pada semua parameter.
\end{abstract}

\section{Kata Kunci: Mentimun, Pupuk Organik Cair, Teknik Aplikasi}

\begin{abstract}
The cultivation of cucumber (Cucumis sativus L.) in the District of Bandongan, Magelang Regency is still limited and has not been cultivated intensively because farmers have not used organic fertilizer. Organic fertilizers can be given in liquid form and need to pay attention to the optimum concentration and application method. This study aims to determine the concentration of liquid organic fertilizer and application techniques that provide the highest yields on cucumber and analyze the interaction between the concentration of liquid organic fertilizer and application techniques on the yield of cucumber. The study was conducted in June to August 2019 in Banyuwangi Village,
\end{abstract}




\section{I.UMIBUNG}

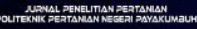

Bandongan District, Magelang Regency, altitude of 382 meter, Latosol soil type and pH 6,6. The study was conducted in factorial experiment $\left(\begin{array}{lll}4 & x & 2\end{array}\right)$ arranged in a complete randomized block design with three blocks. The first factor concentration of liquid organic fertilizer : 0, 2, 4, and $6 \mathrm{ml} / \mathrm{L}$. The second factor for application techniques : spraying and leaking. The data obtained were analyzed by analysis of variance and continued with the orthogonal polynomial test and LSD for the first factor and $t$-test for the second factor. The results of the analysis showed that the concentration of liquid organic fertilizer of 2 $\mathrm{ml} / \mathrm{L}$ gave the highest on plant length, weight per fruit, fruit length and fruit volume. The treatment of the application technique and the interaction between the concentration of liquid organic fertilizer and application techniques give different results which are not significantly different to all parameters.

\section{Keywords: Cucumber, Liquid Organic Fertilizer, Application Technique}

\section{PENDAHULUAN}

Mentimun merupakan salah satu sayuran buah yang sangat populer di kalangan masyarakat, memiliki rasa yang segar dan biasa dijadikan sebagai lalapan. Tanaman mentimun dapat ditanam mulai dari dataran rendah sampai dataran tinggi karena memiliki tingkat adaptasi yang cukup tinggi. Berdasarkan data BPS Jawa Tengah tahun 2017, Kabupaten Magelang merupakan daerah yang menghasilkan produksi mentimun tertinggi yaitu sebesar 75.822 kuintal (BPS, 2018 ). Sentra produksi mentimun terdapat di Kecamatan Mungkid, Sawangan, Muntilan, Srumbung, Ngluwar, Salam dan Dukun. Kecamatan Bandongan merupakan salah satu daerah di Kabupaten Magelang yang memiliki kondisi lingkungan dan syarat tumbuh yang baik untuk pertumbuhan tanaman mentimun, namun petani mentimun masih terbatas dan pelaksanaan sistem budidayanya belum intensif, karena para petani mentimun masih menggunakan pupuk kimia tanpa penggunaan pupuk organik. Padahal pupuk kimia memiliki efek buruk berkepanjangan pada tanah jika tidak diimbangi dengan pupuk organik. Salah satu jenis pupuk organik yang dapat digunakan sebagai alternatif pendamping pupuk kimia untuk tetap menjaga kesuburan tanah yaitu menggunakan pupuk organik cair (POC). Pupuk organik dalam bentuk cair memiliki keunggulan lebih dibanding dengan pupuk dalam bentuk padat yaitu dapat secara cepat menyediakan unsur hara untuk tanaman karena dengan mudah diserap oleh tanaman.

Penentuan konsentrasi POC yang diberikan pada tanaman perlu dilakukan secara tepat, karena kelebihan dosis yang diberikan pada tanaman dapat mengakibatkan kerusakan, apabila dosisnya terlalu rendah maka pertumbuhan tanaman juga akan 


\section{UMBUNAC}

terhambat. Pengujian konsentrasi POC perlu dilakukan untuk mengetahui konsentrasi optimal yang dapat meningkatkan hasil tanaman mentimun, pengujian konsentrasi ini dapat dilakukan dengan membandingkan antara perlakuan tanpa pemberian POC, konsentrasi rendah sampai dengan konsentrasi tinggi yang bertujuan untuk mengetahui seberapa besar pengaruhnya terhadap tanaman mentimun. Selain konsentrasi pupuk organik cair, teknik pengaplikasian pupuk juga perlu dilakukan secara tepat agar dapat diserap oleh tanaman dengan baik dan dapat memberikan produktivitas dan pertumbuhan yang maksimal bagi tanaman. Teknik pengaplikasian pupuk organik cair dapat dilakukan dengan penyemprotan lewat daun atau dikocorkan lewat tanah di sekitar tanaman. Tingkat keefektifan kombinasi perlakuan antara konsentrai POC dan teknik aplikasi ini belum banyak diketahui seberapa besar pengaruhnya terhadap hasil tanaman mentimun.

Penelitian ini bertujuan untuk mengetahui konsentrasi pupuk organik cair dan teknik aplikasi yang memberikan hasil tertinggi pada tanaman mentimun serta menganalisis interaksi antara konsentrasi pupuk organik cair dan teknik aplikasi pupuk terhadap hasil tanaman mentimun (Cucumis sativus L.). Pemberian pupuk organik cair dengan konsentrasi $2 \mathrm{ml} / \mathrm{L}$ dan teknik aplikasi disemprot akan memberikan hasil tanaman mentimun (Cucumis sativus L.) yang tertinggi. Hasil penelitian ini diharapkan dapat digunakan sebagai informasi untuk petani mengenai manfaat penggunaan pupuk organik cair dalam peningkatan hasil tanaman mentimun.

\section{METODE PENELITIAN}

Penelitian dilaksanakan pada bulan Juni 2019 sampai Agustus 2019 di Desa Banyuwangi, Kecamatan Bandongan, Kabupaten Magelang dengan ketinggian tempat 382 $\mathrm{m}$ dpl, jenis tanah Latosol dengan $\mathrm{pH}$ 6,6 pada lahan seluas $273 \mathrm{~m}^{2}$. Penelitian menggunakan metode faktorial $(4 \times 2)$ yang disusun dalam Rancangan Acak Kelompok Lengkap (RAKL). Penelitian terdiri dari dua faktor perlakuan dan diulang tiga kali sebagai kelompok. Faktor tersebut adalah :

Faktor 1 : Pupuk Organik Cair (P), dengan Faktor 2: Teknik Aplikasi (T), dengan taraf taraf sebagai berikut:
$\mathrm{P}_{1} \quad: 0 \mathrm{ml} / \mathrm{L}$
$\mathrm{P}_{2} \quad: 2 \mathrm{ml} / \mathrm{L}$
$\mathrm{T}_{1} \quad$ : Disemprot
$\mathrm{P}_{3} \quad: 4 \mathrm{ml} / \mathrm{L}$
$\mathrm{T}_{2} \quad$ : Dikocor
$\mathrm{P}_{4} \quad: 6 \mathrm{ml} / \mathrm{L}$ sebagai berikut:

Sehingga diperoleh 8 kombinasi perlakuan yaitu:

$\begin{array}{llll}\mathrm{P}_{1} \mathrm{~T}_{1} & \mathrm{P}_{2} \mathrm{~T}_{1} & \mathrm{P}_{3} \mathrm{~T}_{1} & \mathrm{P}_{4} \mathrm{~T}_{1} \\ \mathrm{P}_{1} \mathrm{~T}_{2} & \mathrm{P}_{2} \mathrm{~T}_{2} & \mathrm{P}_{3} \mathrm{~T}_{2} & \mathrm{P}_{4} \mathrm{~T}_{2}\end{array}$ 


\section{I.UMIBUNG}

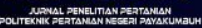

Data hasil pengamatan dianalisis menggunakan sidik ragam dan dilanjutkan uji orthogonal polynomial untuk macam konsentrasi pupuk organik cair dan uji LSD untuk teknik aplikasi pupuk organik cair.

Alat yang digunakan pada penelitian yaitu cangkul, soil tester, altimeter, tugal, patok, sprayer, bambu, tali rafia, gunting, meteran, timbangan digital, jangka sorong, gelas ukur, penggaris, dan alat tulis. Bahan yang digunakan yaitu benih mentimun varietas Harmony, pupuk kandang sapi, jerami padi, POC Nasa, bahan perekat Tunggak Semi, pupuk Urea, pupuk SP - 36, pupuk KCl, Kanon 400 EC.

\section{HASIL DAN PEMBAHASAN}

Hasil penelitian menunjukkan beberapa parameter yang dapat diamati untuk mengetahui pengaruh berbagai konsentrasi pupuk organik cair (POC) dan teknik aplikasi terhadap hasil tanaman mentimun. Data rata - rata hasil pengamatan seluruh parameter tertera pada Tabel 1 .

Tabel 1. Rata - Rata Hasil Pengamatan Seluruh Parameter

\begin{tabular}{cccccccc}
\hline Perlakuan & $\begin{array}{c}\text { Panjang } \\
\text { Tanaman } \\
(\mathrm{cm})\end{array}$ & $\begin{array}{c}\text { Jumlah } \\
\text { Buah per } \\
\text { Tanaman } \\
\text { (buah) }\end{array}$ & $\begin{array}{c}\text { Berat per } \\
\text { Buah }(\mathrm{g})\end{array}$ & $\begin{array}{c}\text { Panjang } \\
\text { Buah } \\
(\mathrm{cm})\end{array}$ & $\begin{array}{c}\text { Diameter } \\
\text { Buah }(\mathrm{cm})\end{array}$ & $\begin{array}{c}\text { Volume } \\
\text { Buah } \\
(\mathrm{ml})\end{array}$ & $\begin{array}{c}\text { Berat } \\
\text { buah per } \\
\text { tanaman } \\
(\mathrm{g})\end{array}$ \\
\hline $\mathrm{P}_{1} \mathrm{~T}_{1}$ & 151,722 & 4,556 & 362,282 & 20,714 & 4,857 & 360,639 & 1591,000 \\
$\mathrm{P}_{1} \mathrm{~T}_{2}$ & 140,222 & 4,333 & 310,744 & 19,968 & 4,576 & 306,713 & 1298,500 \\
$\mathrm{P}_{2} \mathrm{~T}_{1}$ & 198,589 & 4,222 & 379,162 & 22,132 & 4,646 & 384,306 & 1592,556 \\
$\mathrm{P}_{2} \mathrm{~T}_{2}$ & 157,722 & 3,333 & 413,620 & 22,088 & 4,875 & 411,512 & 1299,333 \\
$\mathrm{P}_{3} \mathrm{~T}_{1}$ & 172,122 & 3,944 & 399,333 & 21,681 & 4,730 & 400,000 & 1413,944 \\
$\mathrm{P}_{3} \mathrm{~T}_{2}$ & 181,556 & 3,778 & 357,954 & 21,908 & 4,781 & 379,599 & 1383,444 \\
$\mathrm{P}_{4} \mathrm{~T}_{1}$ & 151,667 & 3,222 & 329,500 & 19,972 & 4,766 & 333,796 & 992,667 \\
$\mathrm{P}_{4} \mathrm{~T}_{2}$ & 151,222 & 4,000 & 315,722 & 19,530 & 4,543 & 315,417 & 1250,444 \\
\hline
\end{tabular}

Sumber : Data Primer, 2019

Rata - rata hasil pengamatan seluruh parameter pada Tabel 1 menunjukkan hasil tertinggi pada parameter panjang tanaman, panjang buah, dan berat buah per tanaman, sedangkan berat per buah memperoleh hasil rendah pada perlakuan $\mathrm{P}_{2} \mathrm{~T}_{1}$. Hal ini dikarenakan buah mendapatkan ruang dan sinar matahari yang cukup untuk melakukan pemanjangan buah, sedangkan pada tanaman yang memiliki panjang tanaman terendah menghasilkan berat per buah yang rendah yaitu pada perlakuan $\mathrm{P}_{1} \mathrm{~T}_{2}$. Hal ini dijelaskan oleh Sajid, dkk (2016) bahwa fase generatif pada tanaman yang ditandai dengan munculnya bunga akan menyebabkan pertumbuhan tinggi tanaman secara perlahan mulai konstan. Hal ini karena selama proses produksi bunga berlangsung akan memerlukan 


\section{UMAUNNC}

unsur hara yang dibutuhkan dalam proses pembelahan sel guna memproduksi bunga, sehingga suplai unsur hara untuk pertumbuhan tinggi tanaman akan dibagi untuk proses produksi bakal buah, sehingga unsur hara lebih banyak digunakan untuk pembesaran buah.

Pada parameter berat per buah, diameter buah dan volume buah yang tertinggi terdapat pada perlakuan $\mathrm{P}_{2} \mathrm{~T}_{2}$, semakin berat per buah disebabkan oleh besarnya diameter buah, sehingga menyebabkan volume buah juga semakin besar. Prayogi, dkk (2016) menjelaskan bahwa berat segar buah akan mempengaruhi volume buah, karena buah yang memiliki bobot yang berat akan memiliki ukuran dan luas penampang buah yang besar sehingga akan berpengaruh terhadap volume buah.

Data yang dihasilkan dari pengamatan seluruh parameter dianalisis menggunakan sidik ragam dan diperoleh $\mathrm{F}$ - hitung seluruh parameter yang dapat dilihat pada Tabel 2 berikut.

Tabel 2. F Hitung Seluruh Parameter Pengamatan

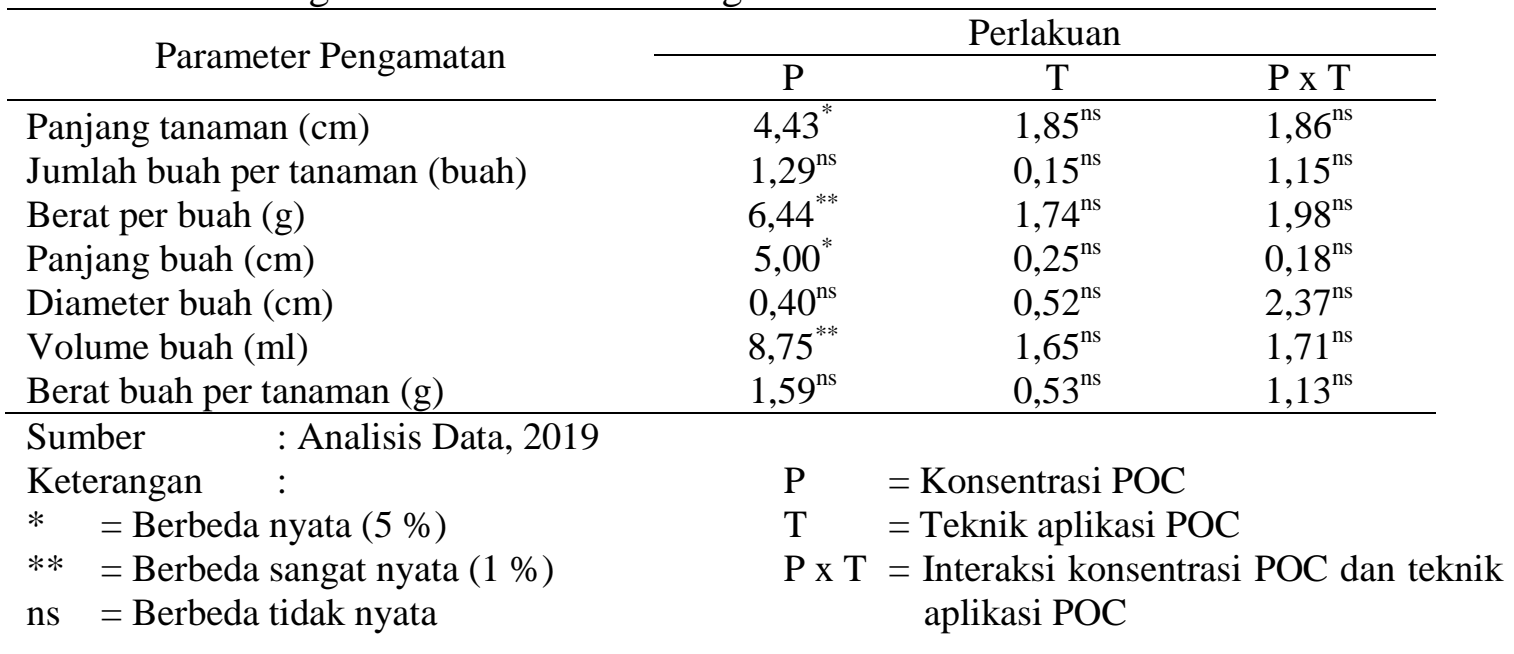

Hasil analisis ragam pada Tabel 2 menunjukkan bahwa perlakuan konsentrasi POC (P) berbeda sangat nyata terhadap berat per buah dan volume buah, serta berbeda nyata pada panjang tanaman dan panjang buah. Namun berbeda tidak nyata pada jumlah buah per tanaman dan berat buah per tanaman. Peningkatan volume buah berbanding lurus dengan berat buah, semakin berat buah maka volumenya juga besar. Selain itu perlakuan POC juga memberikan pengaruh yang nyata pada panjang tanaman dan panjang buah. Perlakuan teknik aplikasi POC (T) dan interaksi antara perlakuan konsentrasi POC dan teknik aplikasi POC (P x T) berbeda tidak nyata pada semua parameter penelitian. 


\section{I.UMIBUNG}

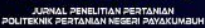

\subsection{Pengaruh Konsentrasi Pupuk Organik Cair (POC)}

\section{Panjang Tanaman (cm)}

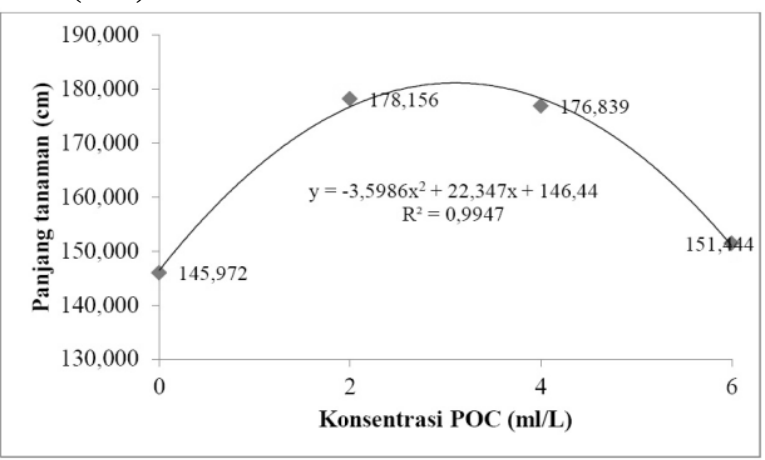

Grafik 1. Pengaruh Konsentrasi POC Terhadap Panjang Tanaman

Hasil uji lanjut pada grafik secara kuadratik tertera pada Grafik 1, dengan persamaan $y=-3,5986 x^{2}+22,347 x+146,44$ dan $R^{2}=0,9947$. Konsentrasi POC $2 \mathrm{ml} / \mathrm{L}$ menghasilkan tanaman terpanjang dibandingkan dengan konsentrasi yang lain. Berdasarkan persamaan di atas juga diperoleh titik optimum pemberian konsentrasi POC yaitu 3,104 $\mathrm{ml} / \mathrm{L}$ dan panjang tanaman $181,078 \mathrm{~cm}$. Penambahan konsentrasi POC akan meningkatkan panjang tanaman sampai pada titik optimum, setelah mencapai titik optimum tersebut, penambahan konsentrasi POC dapat menghambat pertumbuhan tanaman. Konsentrasi tersebut kandungan unsur hara khususnya unsur $\mathrm{N}$ pada pupuk organik cair yang dibutuhkan untuk pertumbuhan vegetatif tanaman mentimun telah tercukupi, sehingga memberikan pengaruh panjang tanaman sampai titik optimum.

Tabel 3. Pengaruh Konsentrasi POC Terhadap Panjang Tanaman (cm)

\begin{tabular}{ccc}
\hline Konsentrasi POC & Rata - Rata & Notasi \\
\hline $0\left(\mathrm{P}_{1}\right)$ & 145,972 & $\mathrm{~B}$ \\
$2\left(\mathrm{P}_{2}\right)$ & 178,156 & $\mathrm{~A}$ \\
$4\left(\mathrm{P}_{3}\right)$ & 176,839 & $\mathrm{~A}$ \\
$6\left(\mathrm{P}_{4}\right)$ & 151,444 & $\mathrm{~B}$ \\
\hline
\end{tabular}

$\begin{array}{ll}\text { Sumber } & \text { : Analisis Data, 2019 } \\ \text { Keterangan } & \text { Angka yang diikuti huruf yang sama tidak berbeda nyata pada uji BNT taraf } 5 \% \\ & =17,106\end{array}$

Perlakuan konsentrasi POC 2 ml/L tidak berbeda nyata dengan konsentrasi POC 4 $\mathrm{ml} / \mathrm{L}$, tetapi berbeda nyata terhadap konsentrasi $0 \mathrm{ml} / \mathrm{L}$ dan $6 \mathrm{ml} / \mathrm{L}$. Konsentrasi $2 \mathrm{ml} / \mathrm{L}$ kandungan unsur hara khususnya unsur $\mathrm{N}$ pada pupuk organik cair yang dibutuhkan untuk pertumbuhan vegetatif tanaman mentimun telah tercukupi dan peningkatan konsentrasi mencapai $6 \mathrm{ml} / \mathrm{L}$ menghambat pertumbuhan panjang tanaman (Tabel 3). Unsur nitrogen sangat dibutuhkan oleh tanaman untuk sintesa asam-asam amino dan protein, terutama 


\section{I.UMIEUNC}

pada titik-titik tumbuh tanaman sehingga mempercepat proses pertumbuhan tanaman seperti pembelahan sel dan perpanjangan sel sehingga meningkatkan tinggi tanaman. Namun adanya unsur hara yang terlalu berlebihan dari yang dibutuhkan akan dapat menyebabkan penurunan hasil tanaman (Dhani, dkk, 2014).

\section{Jumlah Buah Per Tanaman (buah)}

Rata - rata jumlah buah per tanaman yaitu $3-5$ buah. Hasil analisis menunjukkan bahwa konsentrasi POC tidak berpengaruh nyata terhadap jumlah buah per tanaman. Jumlah buah yang hanya sedikit ini disebabkan karena adanya peningkatan pada berat per buah mentimun. Pertumbuhan buah mentimun hanya terfokus pada peningkatan berat buah saja, sehingga jumlah buah yang dihasilkan lebih sedikit. Semakin sedikit buah yang ada, maka semakin besar volume buah dan bobot buah persatuan buah, hal ini disebabkan fotosintat yang dihasilkan oleh daun hanya terkonsentrasi kepada buah yang tidak terlalu banyak, sehingga bobot satuan buah akan meningkat, sedangkan tanaman yang memiliki jumlah buah lebih banyak akan menurunkan bobot satuan buah, penurunan ukuran buah dengan semakin banyaknya buah disebabkan oleh fotosintat yang dihasilkan tidak cukup untuk meningkatkan ukuran buah (Zamzami, 2015).

\section{Berat Per Buah (gram)}

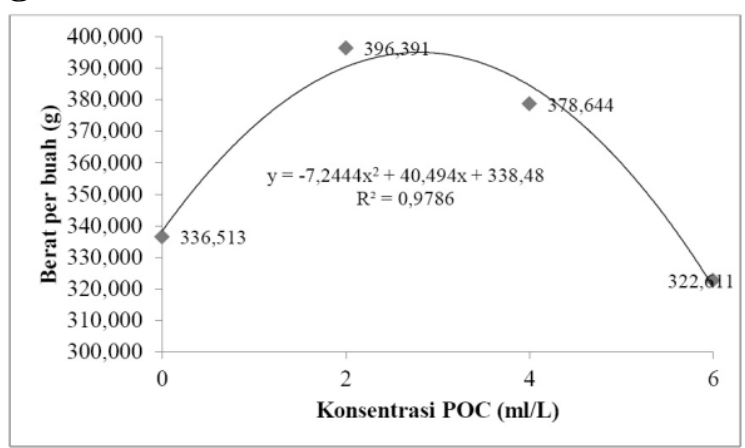

Grafik 2. Pengaruh Konsentrasi POC Terhadap Berat Per Buah

Hasil uji lanjut pada Grafik 2 menunjukkan pengaruh konsentrasi POC terhadap berat per buah menghasilkan grafik secara kuadratik dengan persamaan $\mathrm{y}=-7,2444 \mathrm{x}^{2}+$ $40,494 x+338,48\left(R^{2}=0,9786\right)$ dan hasil tertinggi terdapat pada perlakuan $2 \mathrm{ml} / \mathrm{L}$. Dari persamaan tersebut juga diperoleh titik optimal yaitu pada konsentrasi POC sebesar 2,795 $\mathrm{ml} / \mathrm{L}$ yang menghasilkan berat per buah sebesar 395,06 gram. Semakin tinggi konsentrasi POC yang diberikan pada tanaman mentimun, dapat menghambat peningkatan berat per buah sehingga berat per buah lebih ringan. Penambahan konsentrasi POC yang semakin tinggi akan mencapai titik dimana hasil tidak dapat bertambah lagi. Pemberian pupuk cair 


\section{I.UMIBUNG}

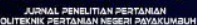

seperti POC Nasa sampai dengan konsentrasi tertentu dapat memperbaiki hasil buah tanaman, namun bila konsentrasi pupuk tersebut ditingkatkan lagi dapat menurunkan hasil buah tanaman (Lidya, 2018).

Tabel 4. Pengaruh Konsentrasi POC Terhadap Berat per Buah (gram)

\begin{tabular}{ccc}
\hline Konsentrasi POC & Rata - Rata & Notasi \\
\hline $0\left(\mathrm{P}_{1}\right)$ & 336,513 & $\mathrm{~b}$ \\
$2\left(\mathrm{P}_{2}\right)$ & 396,391 & $\mathrm{a}$ \\
$4\left(\mathrm{P}_{3}\right)$ & 378,644 & $\mathrm{a}$ \\
$6\left(\mathrm{P}_{4}\right)$ & 322,611 & $\mathrm{~b}$ \\
\hline
\end{tabular}

Sumber : Analisis Data, 2019

Keterangan : Angka yang diikuti huruf yang sama tidak berbeda nyata pada uji BNT taraf $1 \%$ $=40,704$

Tabel 4 menunjukkan bahwa perlakuan konsentrasi POC $2 \mathrm{ml} / \mathrm{L}$ tidak berbeda nyata dengan konsentrasi POC $4 \mathrm{ml} / \mathrm{L}$, tetapi berbeda nyata terhadap konsentrasi $0 \mathrm{ml} / \mathrm{L}$ dan $6 \mathrm{ml} / \mathrm{L}$. Pemberian POC dengan konsentrasi $2 \mathrm{ml} / \mathrm{L}$ dapat menghasilkan berat per buah tertinggi sebesar 396,391 gram. Peningkatan berat per buah ini disebabkan juga adanya peranan unsur fosfor $(0,03 \%)$ dan kalium $(0,31 \%)$ yang terkandung pada pupuk organik cair Nasa. Proses pembentukan buah hara yang sangat berperan adalah $\mathrm{P}$ dan $\mathrm{K}$. Peningkatan bobot buah di pengaruhi oleh tercukupinya hara K karena hara ini berperan dalam translokasi karbohidrat dan pembentukan pati (Imran, 2017).

\section{Panjang Buah (cm)}

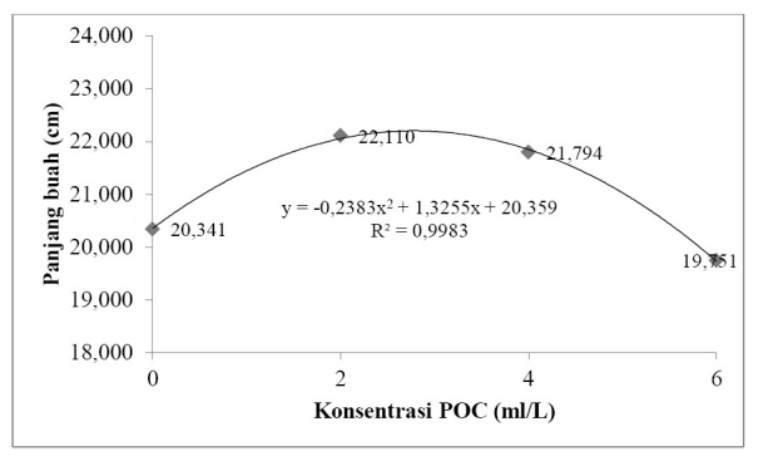

Grafik 3. Pengaruh Konsentrasi POC Terhadap Panjang Buah

Pengaruh konsentrasi POC terhadap panjang buah pada grafik secara kuadratik dengan persamaan $y=-0,2383 x^{2}+1,3255 x+20,359\left(R^{2}=0,9983\right)$. Titik optimum konsentrasi POC yaitu 2,785 ml/L dengan panjang buah sebesar 22,205 cm. Peningkatan konsentrasi POC sejalan dengan peningkatan panjang buah sampai titik optimum, peningkatan konsentrasi POC setelah mencapai titik optimum tersebut mengakibatkan buah menjadi lebih pendek. 


\section{I.UMRUNG}

Tabel 5. Pengaruh Konsentrasi POC Terhadap Panjang Buah $(\mathrm{cm})$

\begin{tabular}{ccc}
\hline Konsentrasi POC & Rata - Rata & Notasi \\
\hline $0\left(\mathrm{P}_{1}\right)$ & 20,341 & $\mathrm{~b}$ \\
$2\left(\mathrm{P}_{2}\right)$ & 22,110 & $\mathrm{a}$ \\
$4\left(\mathrm{P}_{3}\right)$ & 21,794 & $\mathrm{a}$ \\
$6\left(\mathrm{P}_{4}\right)$ & 19,751 & $\mathrm{~b}$ \\
\hline
\end{tabular}

Sumber : Analisis Data, 2019

Keterangan : Angka yang diikuti huruf yang sama tidak berbeda nyata pada uji BNT taraf 5\% $=1,087$

Tabel 5 menunjukkan bahwa perlakuan konsentrasi POC $2 \mathrm{ml} / \mathrm{L}$ tidak berbeda nyata dengan konsentrasi POC $4 \mathrm{ml} / \mathrm{L}$, tetapi berbeda nyata terhadap konsentrasi $0 \mathrm{ml} / \mathrm{L}$ dan $6 \mathrm{ml} / \mathrm{L}$. Pemberian POC dengan konsentrasi $2 \mathrm{ml} / \mathrm{L}$ dapat menghasilkan panjang buah tertinggi yaitu 22,110 $\mathrm{cm}$ dan terendah pada konsentrasi $6 \mathrm{ml} / \mathrm{L}$ yaitu $19,751 \mathrm{~cm}$. Peningkatan konsentrasi POC dapat menurunkan panjang buah. Hal ini dikarenakan salah satu faktor lingkungan yang sangat menentukan laju pertumbuhan perkembangan dan produksi tanaman adalah tersedia unsur hara, apabila tersedia dalam jumlah yang sedikit akan menghambat laju perkembangan, khususnnya organ vegetatif dan generatif. Sebaliknya jika tersedia dalam jumlah yang berlebihan atau melampaui batas maksimum, juga akan berdampak negatif terhadap proses metabolisme tanaman dalam pertumbuhan dan perkembangannya (Imran, 2017).

\section{Diameter Buah (cm)}

Hasil analisis parameter diameter buah menjelaskan bahwa konsentrasi POC tidak berpengaruh nyata terhadap diameter buah. Pada penelitian Andri, dkk (2015) juga menyatakan pemberian POC Nasa tidak berpengaruh nyata pada peningkatan diameter buah. Hal ini menunjukkan meskipun pemberian POC dapat meningkatkan berat per buah, namun tidak selalu menghasilkan diameter buah yang lebih tinggi, karena juga akan ditentukan oleh komponen buah lainnya seperti panjang buah. Peningkatan panjang buah yang lebih besar dibandingkan dengan peningkatan lebar buah sehingga hasil diameter buah menjadi lebih rendah. Ukuran buah lebih dikendalikan oleh faktor genetik dibandingkan dengan faktor lingkungan (Lakitan, 2011). 


\section{I.UMIBUNG}

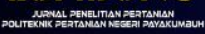

\section{Volume buah (ml)}

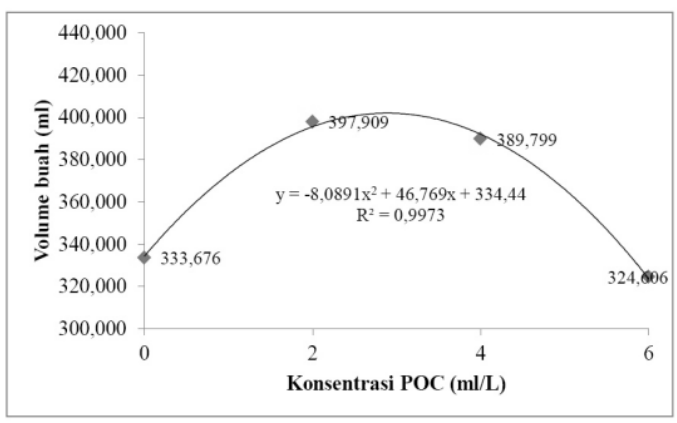

Grafik 4. Pengaruh Konsentrasi POC Terhadap Volume Buah

Hasil uji lanjut orthogonal polynomial pada grafik 4 menunjukkan bahwa pengaruh konsentrasi POC terhadap volume buah membentuk grafik secara kuadratik dengan persamaan $y=-8,0891 x^{2}+47,769 x+334,44\left(R^{2}=0,9973\right)$. Dari persamaan tersebut didapatkan titik optimal yaitu konsentrasi POC 2,891 ml/L menghasilkan volume buah sebesar 402,03 ml. Peningkatan konsentrasi POC sejalan dengan peningkatan volume buah sampai titik optimum, kemudian peningkatan konsentrasi POC setelah mencapai titik optimum menyebabkan penurunan volume buah.

Tabel 6. Pengaruh Konsentrasi POC Terhadap Volume Buah (ml)

\begin{tabular}{ccc}
\hline Konsentrasi POC & Rata - Rata & Notasi \\
\hline $0\left(\mathrm{P}_{1}\right)$ & 333,676 & $\mathrm{~b}$ \\
$2\left(\mathrm{P}_{2}\right)$ & 397,909 & $\mathrm{a}$ \\
$4\left(\mathrm{P}_{3}\right)$ & 389,799 & $\mathrm{a}$ \\
$6\left(\mathrm{P}_{4}\right)$ & 324,606 & $\mathrm{~b}$ \\
\hline
\end{tabular}

Sumber : Analisis Data, 2019

Keterangan : Angka yang diikuti huruf yang sama tidak berbeda nyata pada uji BNT taraf $1 \%$ $=37,928$

Tabel 6 menunjukkan bahwa perlakuan konsentrasi POC $2 \mathrm{ml} / \mathrm{L}$ tidak berbeda nyata dengan konsentrasi POC $4 \mathrm{ml} / \mathrm{L}$, tetapi berbeda nyata terhadap konsentrasi $0 \mathrm{ml} / \mathrm{L}$ dan $6 \mathrm{ml} / \mathrm{L}$. Rata - rata volume buah tertinggi yaitu dicapai pada konsentrasi POC $2 \mathrm{ml} / \mathrm{L}$ yaitu 397,909 ml. Pada perlakuan $4 \mathrm{ml} / \mathrm{L}$ menghasilkan volume buah sebesar 389,799 ml, kedua hasil tersebut lebih tinggi jika dibandingkan dengan perlakuan konsentrasi $0 \mathrm{ml} / \mathrm{L}$ (333,676 ml), dan yang paling rendah dihasilkan pada perlakuan $0 \mathrm{ml} / \mathrm{L}(324,606 \mathrm{ml})$. Ukuran volume buah berbanding lurus dengan berat per buah. Semakin berat buah, maka volumenya juga semakin besar. Peningkatan berat buah disebabkan adanya unsur hara makro dan mikro yang terdapat pada pupuk organik cair. Pemberian POC dapat 


\section{I.UMAUNAC}

meningkatkan ketersediaan unsur hara untuk tanaman mentimun, sehingga akan berpengaruh terhadap pembentukan buah (Lidya, 2018).

\section{Berat Buah Per Tanaman (Buah)}

Penelitian ini menghasilkan berat per buah yang besar tetapi jumlah buah pada masing - masing perlakuan hanya sedikit, sehingga total berat buah per tanaman pada tiap perlakuan tidak menunjukkan perbedaan yang nyata. Berdasarkan hasil analisis juga menunjukkan bahwa konsentrasi POC tidak berpengaruh nyata terhadap berat buah per tanaman. Hasil berat buah per tanaman sebanding dengan jumlah buah per tanaman. Jumlah buah per tanaman yang tidak berbeda nyata juga berpengaruh terhadap berat buah per tanaman yang juga tidak beda nyata. Hasil rata - rata jumlah buah per tanaman pada penelitian ini yaitu $3-4$ buah. Jumlah buah ini termasuk sedikit jika dibandingkan pada deskripsi tanaman mentimun varietas Harmony yang dapat mencapai 8 buah. Semakin sedikit jumlah buah per tanaman yang dihasilkan, maka berat buah per tanamannya juga rendah. Masing-masing tanaman memiliki kemampuan tertentu dalam membentuk jumlah buah yang sangat dipengaruhi oleh faktor dalam tanaman dan faktor lingkungan (Lidya, 2018).

\subsection{Pengaruh Teknik Aplikasi POC}

Teknik aplikasi POC pada penelitian ini dilakukan dengan dua cara yaitu disemprot menggunakan sprayer pada daun dan dikocor atau disiramkan ke bagian akar tanaman. Data seluruh parameter pengamatan yang dihasilkan dianalisis uji - $\mathrm{t}$ untuk mengetahui perbedaan parsial pada masing - masing faktor teknik aplikasi yaitu dengan cara disemprot $\left(\mathrm{T}_{1}\right)$ dan dikocor $\left(\mathrm{T}_{2}\right)$. Hasil analisis uji - $\mathrm{t}$ tertera pada Tabel 7 yang menunjukkan terdapat perbedaan rerata pada semua parameter yaitu panjang tanaman, jumlah buah per tanaman, berat per buah, panjang buah, diameter buah, volume buah dan berat buah per tanaman. Rata - rata hasil pada perlakuan dengan teknik semprot $\left(\mathrm{T}_{1}\right)$ lebih besar jika dibandingkan dengan perlakuan dengan teknik dikocor $\left(\mathrm{T}_{2}\right)$. Namun hasil tersebut tidak signifikan (ns), hal ini dikarenakan hasil uji - $\mathrm{t}$ lebih kecil dari angka $\mathrm{t}$ - tabel dan hasil angka signifikasi lebih dari 0,05 yaitu pada taraf $5 \%$. 


\section{I.UMIBUNC}

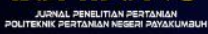

Tabel 7. Uji - t Beda Rerata Pada Perlakuan Teknik Aplikasi

\begin{tabular}{|c|c|c|c|c|c|c|}
\hline \multirow{2}{*}{ Parameter } & \multicolumn{2}{|c|}{ Rata - Rata } & \multirow{2}{*}{$\begin{array}{c}\mathrm{T}- \\
\text { Hitung }\end{array}$} & \multirow{2}{*}{$\begin{array}{l}\mathrm{T}- \\
\text { Tabel }\end{array}$} & \multicolumn{2}{|c|}{ Signifikasi } \\
\hline & $\mathrm{T}_{1}$ & $\mathrm{~T}_{2}$ & & & $\mathrm{~T}_{1}$ & $\mathrm{~T}_{2}$ \\
\hline Panjang tanaman $(\mathrm{cm})$ & 168,524 & 157,681 & 1,021 & 2,145 & $0,318^{\mathrm{ns}}$ & $0,318^{\mathrm{ns}}$ \\
\hline $\begin{array}{l}\text { Jumlah buah per tanaman } \\
\text { (buah) }\end{array}$ & 3,985 & 3,861 & 0,380 & 2,145 & $0,708^{\mathrm{ns}}$ & $0,708^{\mathrm{ns}}$ \\
\hline Berat per buah (gram) & 367,568 & 349,511 & 0,866 & 2,145 & $0,396^{\mathrm{ns}}$ & $0,397^{\mathrm{ns}}$ \\
\hline Panjang buah $(\mathrm{cm})$ & 21,125 & 20,874 & 0,386 & 2,145 & $0,703^{\mathrm{ns}}$ & $0,704^{\mathrm{ns}}$ \\
\hline Diameter buah $(\mathrm{cm})$ & 4,749 & 4,694 & 0,669 & 2,145 & $0,510^{\mathrm{ns}}$ & $0,512^{\mathrm{ns}}$ \\
\hline Volume buah (ml) & 369,685 & 353,311 & 0,795 & 2,145 & $0,435^{\mathrm{ns}}$ & $0,437^{\mathrm{ns}}$ \\
\hline Berat buah per tanaman (gram) & 1397,541 & 1307,929 & 0,676 & 2,145 & $0,506^{\mathrm{ns}}$ & $0,506^{\mathrm{ns}}$ \\
\hline
\end{tabular}

Sumber : Analisis Data, 2019

Keterangan :

$\mathrm{T}_{1}=$ Teknik Semprot

$\mathrm{T}_{2}=$ Teknik Kocor

* = Berbeda Nyata (Signifikasi < taraf 0,05)

ns $=$ Berbeda Tidak Nyata $($ Signifikasi $>$ taraf 0,05)

Perlakuan teknik aplikasi POC dengan penyemprotan pada daun lebih efektif daripada pengocoran lewat akar, karena penyerapan hara yang diberikan berjalan lebih cepat langsung masuk pada stomata daun daripada pupuk yang diberikan lewat akar (Tabel 7). Hasil analisis uji - t menunjukkan bahwa teknik aplikasi lewat daun dan akar berbeda tidak nyata. Padahal seharusnya teknik aplikasi penyemprotan melalui daun lebih baik daripada melalui akar. Pupuk yang masuk lewat daun belum maksimal dikarenakan waktu aplikasi pemupukan tidak diseragamkan. Pelaksanaan pemupukan saat umur 7 HST dilakukan pada pagi hari, saat umur 14 HST dan 21 HST dilakukan pada sore hari. Perbedaan waktu aplikasi ini, kondisi terbukanya stomata pada daun antara pagi dan sore tidak sama yang menyebabkan jumlah unsur hara yang diterima oleh stomata tidak seragam atau tidak dapat maksimal. menyatakan bahwa stomata tumbuhan pada umumnya membuka pada saat matahari terbit dan menutup pada saat matahari mulai gelap. Proses pembukaan memerlukan waktu sekitar 1 jam, dan penutupan berlangsung secara bertahap sepanjang sore, selanjutnya untuk mengetahui produktivitas tanaman dapat dilakukan pemupukan melalui daun pada waktu pagi, dikarenakan mulut stomata membuka sempurna pada waktu pagi, pada siang hari mulut stomata menutup untuk mengurangi penguapan dan kembali membuka pada sore hari tetapi tidak sebesar waktu pagi. Apabila waktu aplikasi pemupukan berbeda, maka menyebabkan penyerapan unsur hara yang masuk lewat stomata juga akan berbeda dan menyebabkan pengaruhnya sangat kecil pada pertumbuhan dan hasil tanaman (Mutaqin, dkk, 2016 dan Meirana, dkk, 2007 dalam Sinuraya, dkk, 2015) 


\section{I.UMBUNAC}

\subsection{Interaksi Konsentrasi POC dan Teknik Aplikasi POC}

Penentuan konsentrasi dan teknik aplikasi POC pada tanaman perlu dilakukan secara tepat agar dapat memberikan pengaruh yang efektif pada tanaman. Pemberian POC pada tanaman mentimun dapat mendukung kualitas buah mentimun yang dihasilkan. Berdasarkan hasil analisis pada penelitian ini (Tabel 1) menunjukkan bahwa konsentrasi dan teknik aplikasi POC berbeda tidak nyata pada semua parameter yaitu panjang tanaman, jumlah buah per tanaman, berat per buah, panjang buah, diameter buah, volume buah dan berat buah per tanaman. Karena pada perlakuan teknik aplikasi POC menunjukkan hasil yang berbeda tidak nyata, sedangkan pada perlakuan konsentrasi POC dapat mempengaruhi pertumbuhan tanaman pada panjang tanaman, dan mempengaruhi hasil tanaman pada berat per buah, panjang buah, dan volume buah. Hal ini menunjukkan bahwa adanya perlakuan konsentrasi POC khususnya pada konsentrasi $2 \mathrm{ml} / \mathrm{L}$ yang diberikan pada tanaman mentimun dapat mempengaruhi hasil tanaman dan tidak bergantung pada teknik aplikasi atau cara pemberian pupuk pada tanaman.

\section{KESIMPULAN}

1. Perlakuan konsentrasi POC $2 \mathrm{ml} / \mathrm{L}$ mempengaruhi hasil tanaman mentimun dengan memberikan hasil tertinggi pada parameter panjang tanaman, berat per buah, panjang buah dan volume buah.

2. Teknik aplikasi POC dengan cara disemprot dan dikocor menunjukkan perbedaan pada hasil rata - rata semua parameter pengamatan. Rata - rata hasil pada perlakuan dengan teknik semprot $\left(\mathrm{T}_{1}\right)$ lebih besar jika dibandingkan dengan perlakuan dengan teknik dikocor $\left(\mathrm{T}_{2}\right)$. Namun hasil tersebut tidak signifikan, hal ini dikarenakan angka $\mathrm{t}$ - hitung yang dihasilkan lebih kecil dari angka $\mathrm{t}$ - tabel dan hasil angka signifikasi lebih dari 0,05 pada taraf 5\%.

3. Interaksi perlakuan konsentrasi dan teknik aplikasi POC berbeda tidak nyata pada semua parameter hasil tanaman mentimun. Pada perlakuan teknik aplikasi POC menunjukkan keduanya berbeda tidak nyata, sedangkan pada perlakuan konsentrasi POC menunjukkan adanya pengaruh pada beberapa parameter. Perbedaan pertumbuhan dan hasil tanaman mentimun akibat perbedaan perlakuan konsentrasi POC tidak bergantung pada perbedaan teknik aplikasinya. 


\section{I.UMIBUNG}

\section{REFERENSI}

Badan Pusat Statistik. 2018 a . Statistik Pertanian Hortikultura Provinsi Jawa Tengah 20152017. Badan Pusat Statistik. Jawa Tengah.

Dhani, H, Wardati, dan Rosmini. 2014. Pengaruh Pupuk Vermikompos pada Tanah Inceptisol Terhadap Pertumbuhan dan Hasil Sawi Hijau (Brassica juncea L.). Jurnal Online Mahasiswa. 1 (1) : 1 - 11.

Imran, A. N. 2017. Pengaruh Berbagai Media Tanam dan Pemberian Konsentrasi Pupuk Organik Cair (POC) Bio-Slurry terhadap Produksi Tanaman Melon (Cucumis melo L.). Jurnal Agrotan. 3 (1) : 18 - 31.

Lakitan. 2011. Dasar - dasar Fisiologi Tumbuhan. PT. Raja Grafindo Persada. Jakarta.

Lidya, E, Noor, J, dan Abdul, R. 2018. Pengaruh Pupuk Kompos dan Pupuk Organik Cair Nasa Terhadap Pertumbuhan dan Hasil Tanaman Mentimun (Cucumis sativus L.) Varietas Misano F1. Jurnal Agrifor Volume. 1 (17) : 89 - 96.

Mutaqin, A. Z, Ruly B, Tia S, Mohamad N, dan Radewi S. F. 2016. Studi Anatomi Stomata Daun Mangga (Mangifera indica) Berdasarkan Perbedaan Lingkungan. Jurnal Biodjati. 1 (1) : $13-18$.

Prayogi, A, Adiwirman dan Khoiri, M. A. 2016. Studi Mutu Buah Kelapa Sawit (Elaeis guineensis Jacq.) pada Berbagai Umur Tanaman di Lahan Gambut. JOM Faperta. $2(2): 1-10$.

Sajid, F. Budiyanto, G. dan Mulyono. 2016. Aplikasi Briket Gliricidae-Arang Sekam dalam Upaya Meningkatkan Efisiensi Pemupukan Tanaman Tomat (Lycopersicum esculentum L.) di Lahan Terpapar Erupsi Merapi 2010. Jurnal Agrosains. 1 (3) : 1 -9 .

Sinuraya, M. A, Asil B, dan Yaya H. 2015. Respons Pertumbuhan dan Produksi Kedelai (Glycine max (L.) Meriil) Terhadap Konsentrasi dan Cara Pemberian Pupuk Organik Cair. Jurnal Agroekoteknologi . 1 (4) : 1721 - 1725.

Zamzami, Nawawi M dan Aini N. 2015. Pengaruh Jumlah Tanaman Per Polibag dan Pemangkasan Terhadap Pertumbuhan dan Hasil Tanaman Mentimun Kyuri (Cucumis Sativus L.). Jurnal Produksi Tanaman. 3 : 113 - 119. 